\title{
The phylogenetic debate on the affinities of graptolites. An attempt at a methodological analysis
}

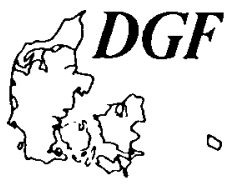

Urbanek, A. The phylogenetic debate on the affinities of graptolites. An attempt at a methodological analysis. Bull. geol. Soc. Denmark, vol. 35, pp. 223-230, Copenhagen, July 1st, 1987.

The debate on the graptolite affinities provides a model of lasting phylogenetic controversy which may be analysed in terms of philosophy of science. As suggested by Popper, all scientific discussions start with a problem formulated within the context of a certain problem situation which develops as a result of the growth of knowledge. About 10 such problem situations may be distinguished in the debate analysed, beginning with the multiparadigmatic stage in the late 19th century. At this time the coelenterate paradigm was elevated to the rank of canonical knowledge of the time. The 1930s saw the culmination of the debate with the revival of classical concepts of graptolite affinities - the coelenterate and the bryozoan paradigms. The most important event was, however, Kozlowski's radical modification of the pterobranch paradigm. The present views on the graptolite ancestry may be directly derived from Kozlowski's great contribution. New palaeontological evidence supplied by Kozlowski, and the palaebiochemical studies by Foucart et al. in 1960s outweighed the alternative viewpoints and Kozlowski's concepts were generally accepted.

The TEM studies by Urbanek and Towe detected, however, an esssential dissimilarity in the ultrastructure of the graptolite and the pterobranch periderms. This anomaly was difficult to explain within the framework of Kozłowski's concepts and led to Urbanek's temporary revival of views declaring the graptolite ancestry an open problem. Anders and Crowther and Rickards discovery of cortical bandages provided new evidence for uniform mode of secretion of the pterobranchs and the graptolite skeleton. Recent biochemical data indicating a collagenous nature of the skeleton in pterobranchs in conjunction with the results of the TEM studies on the collagen-like nature of the graptolite skeleton speaks in favour of a close phylogenetic relationship between the groups in question.

A. Urbanek, Institute of Palaeobiology PAS, Unit for Graptolite Research, Newelska 6, 01-447 Warszawa, Poland, October 5th, 1986.

\section{Introduction}

The problem of graptolite affinities provides a classical example of a lasting phylogenetic debate which deserves to be analysed in terms of the philosophy of science. There is no doubt that such an analysis may offer an interesting lesson for palaeontologists as well as for biologists or philosophers. Also the most recent views cannot be considered in isolation from earlier concepts. The current ideas on the graptolite affinities become more understandable when their genealogy is exposed.

According to Popper (1979), all scientific discussions start with selecting a problem (P) to which a tentative solution or a tentative theory (TT) is offered to be later subject to criticism and revision in an attempt at error elimination (EE):

$\mathrm{P}_{1} \rightarrow \mathrm{TT}_{1} \rightarrow \mathrm{EE}_{1} \rightarrow \mathrm{P}_{2} \rightarrow \mathrm{TT}_{2} \rightarrow \mathrm{EE}_{2} \rightarrow \mathrm{P}_{3} \ldots$
Problems (P) are always formulated within the context of a certain problem situation (PS) that develops due to the growth of knowledge. The problem situation exerts a kind of pressure on the way of thinking of a scientists: PS $\rightarrow$ P. This relation implies a loose dependence rather than rigid determinism.

\section{Primary ideas}

Mutatis mutandis, the Popperian scheme may be used when trying to make sense of the extended phylogenetic debate on the ancestry and the systematic position of graptolites.

The essential problem of this debate was formulated early and has remained basically the same troughout the discussion: What are the nearest relatives (if any!) of graptolites or, in other words, what is the systematic position of graptolites in the animal kingdom? 
The formulation of the problem (P) has not been, however, entirely invariant depending largely on the changing elements of the developing problem situation (PS) - thus it has a changing context.

A new problem situation emerged in each case as a result of the growth of knowledge either in the sphere of theoretical generalizations with the ensuing changes in the methodological approach or due to the influx of new data concerning the graptolites and their potential relatives.

The pre-Darwinian period had its own logic and was predominated by the problem of the nature of the graptolite remains:

- were they inorganic or organic? - Carl Linné in "Systema Naturae", 1735;

- were they remains of marine plants? - von Brommel (1727), Brongniart (1828);

- were they fossil cephalopods? - Walch (1771);

- did they have a "polypide" or a generally coelenterate nature? - an idea which appeared around 1830 and is ascribed to Nilsson. Of all possible solution the latter idea proved to be the most fertile and was supported later by many distinguished palaeontologists.

In the post-Darwinian period of the 19th century, the logic of considerations was radically changed owing to the spreading of evolutionary thinking and introduction of phylogenetic notions.

This led to the emergence of a new problem situation ( $\left(\mathrm{PS}_{1}\right)$, and the primary pool of ideas was formulated. About ten (10) problem situations $\left(\mathrm{PS}_{1}-\mathrm{PS}_{10}\right)$ can be tentatively distinguished in the course of the post-Darwinian part of debate on the graptolite affinities; each being the result of an influx of new data involving a certain way of thinking and implying a specific solution of the general problem (P). The old semi-intuitive concepts were partially tested and most of the false views were refuted.

Three main concepts $\left(\mathrm{TT}_{1}-\mathrm{TT}_{3}\right)$ evolved as a result:

1) the coelenterate (and in most cases the hydrozoan) concept (Hall, 1865; Lapworth, 1873; Allman, 1872; Nicholson, 1872),

2) the bryozoan concept (Salter, 1866),

3) the Rhabdopleura or primaeval pterobranch concept (Richter, 1871).
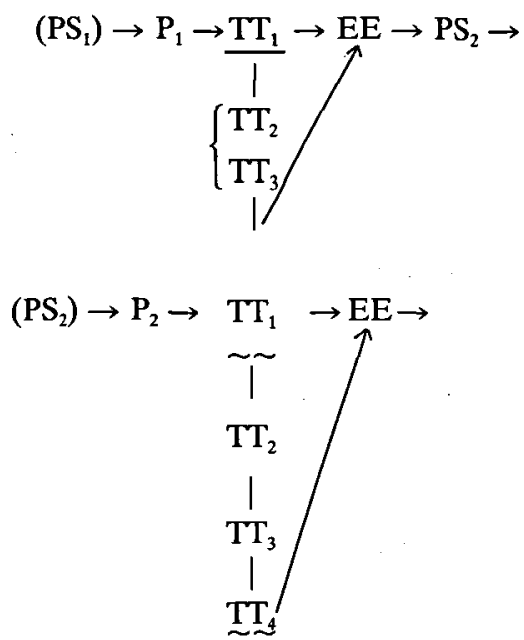

a multiparadigmatic stage

- included into the canonical knowledge (K. Zittel, "Handbuch...". 1880)

$\sim$ the main conflicting tentative theories

Fig. 1. The anatomy of the primary pool of ideas.

The second half of the 19th century was multiparadigmatic with predominance of the coelenterate concept, which was elevated to the status of canonical knowledge in the treatise by $\mathrm{K}$. Zittel (1880) (see diagram below).

C. Wiman's contribution (1895) accounted for a new problem situation $\left(\mathrm{PS}_{2}\right)$. He initiated a revolution in the techniques of graptolite research bringing about a vast increas in the knowledge of the group (see diagram above). C. Wiman (1895) advanced an agnostic theory $\left(\mathrm{TT}_{4}\right)$ that graptolites were unique and had no close affinities with other groups. His views were shared by a number of distinguished palaeotologists such as Perner (1894), Ruedemann (1895), Frech (1897) and Elles (1922).

It was Schepotieff $(1905,1907)$ who created another problem situation ( $\left.\mathrm{PS}_{3}\right)$. He proposed a redifinition of the previous ideas on the pterobranch ancestry to form the pterobranch para$\operatorname{digm}\left(\mathrm{TT}_{3} \rightarrow \mathrm{TT}_{3}{ }^{\prime \prime}\right)$.

It should be noted that Schepotieff's ideas were an odd blend of apt conclusions and their inadequate substantiations. Thus, his conclusions concerning graptolite affinity later proved to be correct, but his homologies were entirely misleading. He believed in the existence of two homologies: between the sicula and the terminal 
portion of the creeping tube in Rhabdopleura and between the stolon of Rhabdopleura and the nema or the virgula in Graptoloids. Moreover, in his considerations Schepotieff underestimated the significance of the peculiar fine structure in both groups, exemplified by the presence of characteristic growth bands.

\section{The great clash of ideas}

The thirties of the 20th century saw a renewed multiparadigmatic stage associated with the redefinition and modernization of the three main paradigms: the coelenterate paradigm (Bulman, 1932, 1937, 1938), the bryozoan paradigm (Ulrich and Ruedemann, 1931), and a completely new version of the pterobranch paradigm (Kozłowski, 1938) - $\mathrm{PS}_{4}$ ).

A great clash of ideas ensued and resulted in the predominance of Kozlowski's pterobranch paradigm (see diagram below). Kozłowski's classical hypothesis was based on new factual grounds: on the histology of the skeleton, and the recognition of its fusellar and cortical components; the specificity of the fusellar structure; and on the composition of the skeleton with its alleged chitinous nature. Moreover, he emphasized the significance of the presence of an internal stolon, as well as the peculiar mode of budding in graptolites.

Kozłowski's views can be summarized in three main conclusions or theses:

a) the morphogenetic thesis, stating the mode of formation of the cortex was unique in graptolites and implies the presence of an extrathecal membrane;

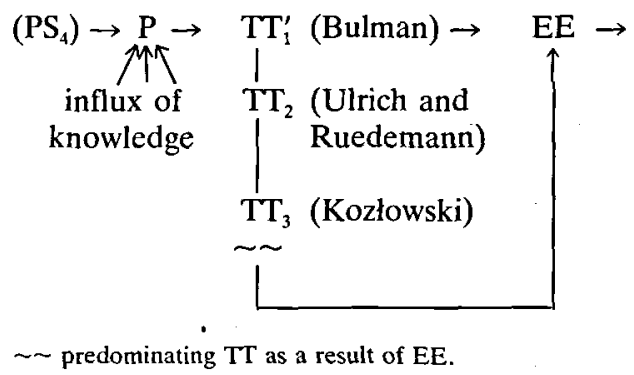

Fig. 2. The renewed multiparadigmatic stage (1930s). b) the phylogenetic thesis, indicating the close affinity between the rhabdopleurid pterobranch and the Graptolithina, and

c) the new concept of the biological organization of the graptolite colonies involved, first and foremost, new interpretation of thecal polymorphism understood as an extreme case of sexual dimorphism. Hence a great difference between the graptolites and the coelenterates whose polymorphism is based on the division of non-sexual functions.

\section{The recognition machinery and the discovery of an anomaly}

The reception of Kozlowski's ideas was delayed because of the outbreak of World War II, but O. M. B. Bulman, the leading authority on graptolites, soon became convinced as to their pterobranch affinity. Bulman restated Kozłowski's main views and corroborated them by his own observations on dendroid graptolites (1942, 1945). Later, Bulman (1949) reported on graptolites, in connection with Kozlowski's discoveries, to the 13th International Congress of Zoology (Paris, 1948).

A great part was also played by the authors of big treatises, especially by Dawydorff (1948) in the "Traité de Zoologie", by Waterlot (1953) in the "Traité de Palaeontologie", by Bulman (1955) in the "Treatise of Invertebrate Palaeontology", and by Beklemishev in his "Principles of Comparative Anatomy of Invertebrates" (1970, 1952, 1964).

Whilst Kozłowski's ideas on the affinities of graptolites were rather widely accepted, there were some doubts concerning his concept of skeletal secretion (compare Bulman 1955, 1970). As a matter of fact, Kozlowski never defined precisely enough the topographical relation between the soft parts and the skeleton. The combination of the pterobranch and the bryozoan mode of secretion proposed by him appeared implausible to some zoologists.

Beklemishev (1951) concluded that the secretion of the graptolite periderm followed entirely the pterobranch mode. By rejecting Kozłowski's morphogenetic concepts but accepting his phylogenetic conclusions he anticipated the most recent developments. 
Successive problem situations (PSS) emerging in the debate on graptolite affinities*.

* (Pre-evolutionary, incipient ideas on the nature and systematic position of graptolites are ommitted.)

\begin{tabular}{|c|c|c|}
\hline $\begin{array}{l}\text { Successive } \\
\text { problem } \\
\text { situations }\end{array}$ & Main events & Resulting theoretical situation \\
\hline $\mathrm{PS}_{1}$ & $\begin{array}{l}\text { Primary pool of ideas } \\
\text { 1860-1895 }\end{array}$ & $\begin{array}{l}\text { multiparadigmatic stage, dominance of the } \\
\text { coelenterate paradigm }\end{array}$ \\
\hline $\mathbf{P S}_{2}$ & $\begin{array}{l}\text { Contribution of Wiman } \\
1895\end{array}$ & formulation of the agnostic paradigm \\
\hline $\mathrm{PS}_{3}$ & $\begin{array}{l}\text { Contribution of Schepotieff } \\
1905\end{array}$ & redefinition of the pterobranch paradigm \\
\hline $\mathrm{PS}_{4}$ & $\begin{array}{l}\text { Redefinition of the coelenterate paradigm (Bulman, 1932, } \\
\text { 1938) and the bryozoan paradigm (Ulrich \& Ruedemann, } \\
\text { 1931); a new version of the pterobranch paradigm offered by } \\
\text { Kozłowski (1938) }\end{array}$ & renewed multiparadigmatic stage \\
\hline $\mathrm{PS}_{5}$ & $\begin{array}{l}\text { Kozłowski's big monograph }(1949) \text { and a series of his dis- } \\
\text { coveries of fossil pterobranchs; Bulman's recognition of Ko- } \\
\text { zlowski's concept }(1942,1955)\end{array}$ & $\begin{array}{l}\text { predominance of the pterobranch paradigm in } \\
\text { Kozlowski's version including morphogenetic } \\
\text { theses }\end{array}$ \\
\hline $\mathrm{PS}_{6}$ & $\begin{array}{l}\text { Criticism against Kozlowski's concept especially the chitin- } \\
\text { protein controversy (Hyman, 1959). }\end{array}$ & $\begin{array}{l}\text { a certain rebirth the coelenterate paradigm } \\
\text { treated as an alternative to the pterobranch } \\
\text { one, hesitant position in the palaeontological } \\
\text { community }\end{array}$ \\
\hline $\mathrm{PS}_{7}$ & $\begin{array}{l}\text { Studies of Foucart et al. }(1964,1965,1966) \text { on palaeoproteins } \\
\text { in graptolite skeleton and proteinaceous nature of pterobranch } \\
\text { skeleton. Kozlowski's defense of his theses. (1966). }\end{array}$ & $\begin{array}{l}\text { strenghening of the pterobranch paradigm } \\
\text { completed by the biochemical data }\end{array}$ \\
\hline $\mathbf{P S}_{8}$ & $\begin{array}{l}\text { Discovery of an "ultrastructural anomaly", in an attempt to } \\
\text { confirm Kozłowski's concept with TEM studies (Towe and Ur- } \\
\text { banek } 1972 \text {, Urbanek \& Tove 1974, 1975, Urbanek 1976) and a } \\
\text { question raised against the validity of Foucart's results in re- } \\
\text { spect of graptolites. Incongruences in Kozlowski's model of se- } \\
\text { cretion exposed and the uniform membrane model of secretion } \\
\text { given preference as compared to the dualistic model of se- } \\
\text { cretion. }\end{array}$ & $\begin{array}{l}\text { renewal of the agnostic position in respect of } \\
\text { the graptolite affinity. Questions raised against } \\
\text { Kozłowski's morphogenetic and phylogenetic } \\
\text { theses. }\end{array}$ \\
\hline $\mathbf{P S}_{9}$ & $\begin{array}{l}\text { Discovery of cortical bandages (Andres, } 1976,1977 \text { Crowther } \\
\text { \& Rickards 1977). Rejection of the membrane for a pte- } \\
\text { robranch ancestry of graptolites because of the uniformity of } \\
\text { secretion and the similarity of structure (Crowther, 1980; An- } \\
\text { dres 1980). }\end{array}$ & $\begin{array}{l}\text { modification of Kozlowski's version of the pte- } \\
\text { robranch paradigm, changing his morphoge- } \\
\text { netic and confirming his phylogenetic thesis. }\end{array}$ \\
\hline $\mathrm{PS}_{10}$ & $\begin{array}{l}\text { Discovery of a collagenous nature of the coenecium in Recent } \\
\text { pterobranchs (Armstrong, Dilly \& Urbanek 1984). }\end{array}$ & $\begin{array}{l}\text { a new synthesis based on biochemical, ultra- } \\
\text { structural and anatomical studies the revival of } \\
\text { a modified pterobranch paradigm including the } \\
\text { thesis on the molecular uniformity of the skel- } \\
\text { etal material. }\end{array}$ \\
\hline
\end{tabular}

The criticism of Kozlowski's ideas in the 1950s led to a temporary rebirth of the coelenterate paradigm within the palaeozoological - zoological community. Bohlin (1950) criticized Kozłowski's concept of the graptolite skeleton secretion and put forward again the coelenterate affinity of graptolites. Decker $(1956,1958)$ suggested a liberal interpretation of the preservational features recognized with what he believed to be a "higher magnification". Hyman (1959) also criticized Kozlowski in her textbook and started a chitin/pro- tein controversy, in fact a "Scheinproblem" stemming from the imperfections of the terminology.

All this resulted in characteristically neutral or indifferent opinions regarding the systematic position of graptolites, e.g. the views of Simpson (1955) or Barrington (1965). One can regard such responses to Kozlowski's ideas and their criticism as a new problem situation $\left(\mathrm{PS}_{6}\right)$ as compared to $\left(\mathrm{PS}_{5}\right)$ which evolved right after the appearance of Kozłowski’s major monograph (1949).

The inflow of new data came from the newly 
emerging field of palaeobiochemistry. In their studies, Foucart et al. $(1964,1965,1966)$ showed the presence of aminoacids in the graptolite skeleton and provided evidence that both the pterobranchs and the graptolites have proteinaceous skeletons $\left(\mathrm{PS}_{7}\right)$.

These discoveries solved for the time being the "chitin/protein controversy" strengthening the pterobranch paradigm $\left(\mathrm{PS}_{7}\right)$.

From this stand, Kozlowski defended his theory which at that point attained the most complete expression $\left(\mathrm{TT}_{2}\right.$ of Kozłowski or $\mathrm{TT}_{3}{ }^{\prime \prime}$ of the pterobranch paradigm).

An attempt at testing Kozlowski's elaborate theory $\left(\mathrm{TT}_{2}\right)$ led, on the one hand, to the discovery in the graptolite skeleton of amazingly well-preserved fabrics indicative of its collagenous nature (Towe and Urbanek, 1972; Urbanek and Towe, 1974, 1975) and, on the other hand, to the recognition of a striking dissimilarity in the ultrastructure of the pterobranch and the graptolite skeleton. This may be called the discovery of an ultrastructural anomaly $\left(\mathrm{PS}_{8}\right)$. The anomaly was a puzzle from the standpoint of the close graptolite/pterobranch affinity.

The discovery of the ultrastructural anomaly would not have been possible without Dilly's (1971) excellent contribution showing the ultrastructure of the zooidal tube in the Recent Rhabdopleura. The same pattern was soon recognized in the Ordovician Rhabdoplerites, thus providing evidence of an invariable ultrastructural difference between the fusellar components of the graptolite and the pterobranch skeleton (Urbanek, 1976).

The earlier recognition of an alleged keratinous nature of the skeletal fibrils in Rhabdopleura also contrasted with the facts indicating the collagenous nature of the graptolite skeletal material.

\section{The period of neo-agnosticism}

This paradoxical problem situation $\left(\mathrm{PS}_{8}\right.$ ) brought about a revival of the agnostic approach to the graptolite affinity. The ultrastructural anomaly seemed to imply fundamental differences between the graptolites and the pterobranchs at the molecular level, undermining the earlier conviction that the microscopic resemblances between the two groups are essential. On the one hand, there was ample TEM evidence of collagenous nature of the skeletal material in graptolites, and on the other, TEM studies revealed a striking dissimilarity between the fibrous material of Pterobranchia and that of graptolites. Hence the question: is the pterobranch skeleton non-collagenous and made of keratin or of some other kind of protein?

Urbanek (1976) arrived at a conclusion that the presumed differences at the molecular level were associated with quite different modes of secretion of the skeleton in pterobranchs and in graptolites. A similar point of view was suggested, by Kirk $(1972,1974)$ in her evaluations of Kozłowski's and Urbanek and Towe's works.

Urbanek (1976) based his neo-agnostic approach on the contradictions exposed by him in Kozlowski's model of secretion, which was proved to be functionally impossible. He raised objections to 1) the morphogenetic thesis of Kozłowski's theory suggesting for graptolites a uniform model af secretion by a sort of membrane, 2) the phylogenetic thesis declaring the problem of graptolite affinity still unresolved and the degree of their kinship with pterobranch difficult to define.

Both points are components of what was Urbanek's new TT, a temporary solution based on the new and growing body of the ultrastructural data.

\section{Towards a solution}

Urbanek's tentative conclusion soon caused much controversy. The light microscope (Andres, 1976, 1977) and SEM studies (Crowther and Rickards, 1977) on the surface micromorphology of graptolites revealed the presence of ribbon - like units, the cortical bandages.

They were considered to be universal units of secretion of the cortical tissue, impying that the whole graptolite skeleton was secreted in the same way as that of pterobranchs.

The uniformity of secretion and the similarity of structure, two strong arguments in support of the pterobranch ancestry of graptolites, were most convincingly advanced by Crowther (1980) and created a new problem situation - $\left(\mathrm{PS}_{9}\right)$. In their highly logical inferences there was one important point which the authors brushed aside. 
That was the problem of the differences at the ultrastructural level. They believed that in the future those differences would be explained somehow. But the question was how! It was clear that a number of open issues could not be solved without a better understanding of the chemical composition of the pterobranch skeleton. This was the logic of a new problem situation ( $\mathrm{PS}_{10}$ ), which developed after the essential uniformity of the mode of secretion had been established with the use the SEM techniques.

The answer has been supplied by the recent paper by Armstrong, Dilly and Urbanek (1984) on the amino-acid composition of the pterobranch skeleton. It is composed of a collagenous material with a high hydroxyproline and low hydrolysine level, although the fibrous material lacks the standard EM characteristics of collagen.

The identification of the collagenous nature of the pterobranch skeleton $\left(\mathrm{PS}_{10}\right)$, taken in conjunction with the presumed presence of collagen in the skeleton of fossil graptolites and with other data now supports the hypothesis that both groups are phylogenetically closely related. The proofs of this affinity can be seen in the molecular and morphogenetic uniformity, as evidenced by the TEM and chemical data on the one hand and by the LM and SEM studies on the other. The ultrastructural incongruence (revealed by the TEM technique) may be due to the remarkable polymorphism of collagen fibrils and does not contradict the close affinity between the Pterobranchia and Graptolithina.

The newly modified paradigm is a synthesis based on biochemical, ultrastructural and anatomical studies... It is a modified pterobranch paradigm which includes the thesis on morphogenetic and molecular uniformity and explains the differences at the ultrastructural level as a secondary effect of the arrangement of the tropocollagen units within the collagen fibrils.

\section{A lesson from the debate}

The long lasting phylogenetic debate on the affinities of graptolites provides a lesson to all the parties of the discussion as well as to all those engaged in phylogenetic studies. As a rule the phylogenetic conclusions are based on incomplete evidence, but striving for clarity and precision we often try to be more exact than the evidence permits and the problem requires. This is the frequent source of errors and instability of opinions.

To be more specific, I personally misunderstood the nature of the ultrastructural differences recognized between graptolites and pterobranchs, but it is also fair to say that these differences were by no means trivial. Perhaps they are among the best diagnostic features of the graptolite grade of the rhabdosome construction. The discovery of an ultrastructural anomaly, that is, of a distinct difference between the Pterobranchia and the Graptolithina in the fusellar component of their skeleton - once the source of misleading conclusions - became, however, the basis of a valuable research programme. Together with the remarkable and independent studies on the SEM micromorphology including the discovery and recognition of the morphogenetic role of the so-called cortical bandages, this research programme was instrumental in reaching a better understanding of the graptolite affinities. The graptolite workers have provided a good example of the Popperian error-elimination, a procedure which corresponds, within his scheme of Evolutionary Epistomology, to the Darwinian selection in nature that usually results in killing the unit in the competitive struggle for life. As one could expect, scientists are less moral than animals, for they "kill" (criticise and refute) only their theories. As Popper (1979: 122) puts it "Scientists try to eliminate their false theories, they try to let them die in their stead".

To be faithful to Karl Popper and to pay tribute to his popularity among naturalists in the last decades, I would quote him once more: "The difference between the amoeba and Einstein is that, although both make use of method of trial and error elimination, the amoeba dislikes to err while Einstein is intrigued by it: he consciously searches for his errors in the hope of learning by their discovery and elimination" (Popper, 1979: 70).

I feel ashamed, but I must confess that not unlike amoeba I rather dislike to err and I am intrigued more by errors of other than by my own. And this is correct - this places me somewhere between the amoeba and Einstein. But I am glad that we can learn from our mistakes and accept those theories which withstand the severe criticism best. 
I am also happy to declare that it seems that as result of the growth of knowledge the graptolites have ceased to be a problematic group, but they still pose quite a few problems.

\section{Dansk sammendrag}

Debatten om graptolitternes fylogenetiske tilhørsforhold kan tjene som et eksempel, der kan underkastes en videnskabsfilosofisk analyse. Som Popper har foreslået, begynder al videnskabelig diskussion med et problem, der er blevet formuleret $\mathbf{i}$ sammenhæng med en situation, der har udviklet sig på grund af øget viden. Omkring 10 sådanne problemsituationer kan udskilles i den førte debat, der starter med multi-model trinnet sent $i$ det nittende århundrede. På dette tidspunkt blev en coelenteratmodel gjort enerådende. I 1930erne kulminerede debatten ved genoplivning af klassiske forestillinger om henholdsvis tilhørsforhold til coelenterater og bryozoer. Den vigtigste nyskabelse var Kozlowski's modifikation med forslaget om en pterobranch tilknytning. De nutidige opfattelser om graptolitternes nedstamning kan direkte afledes fra Kozlowski's betydningsfulde bidrag. Nye palæontologiske resultater fra Kozlowski sammen med paleobiokemiske undersøgelser af Foucart og medarbejdere sejrede over andre opfattelser og Kozlowski's synspunkter blev almindeligt anerkendt.

Elektronmikroskopi afslørede dog betydelige forskelle mellem peridermen hos graptolitter og pterobrancher. Forskellen var vanskelig at forstå inden for Kozłowski's model og førte til et forslag om, at graptolitafstamningen stadig var et åbent spørgsmål. Imidlertid blev der påvist "cortical bandages", der pegede på et identisk mønster for sekretionen hos de to grupper. Nyere biokemiske data peger $\mathrm{i}$ retning af collagen-agtig substans i pterobranch skelettet, og det samme kan vises ved elektronmikroskopi hos graptolitter. Dette taler for en tæt fylogenetisk relation mellem de to grupper.

\section{References}

Allman, G. J. 1872: On the morphology and affinities of graptolites. Ann. Mag. Nat, Hist. 4, 9, 364-380.

Andres, D. 1976: Graptolithen aus ordovizischen Geschieben und die frühe Stammesgeschichte der Graptolithen. Innaugural - Dissertation zur Erlangung der Doktorwürde, $4+75$. Berlin.

Andres, D. 1977: Graptolithen aus ordovizischen Geschieben und die frühe Stammesgeschichte der Graptolithen. Pal. äont. Z. 51, 52-93.

Armstrong, W. G., Dilly, P. N. and Urbanek, A. 1984: Collagen in the pterobranch coenecium and the problem of graptolite affinities. Lethaia, 17, 145-152.

Barrington, E. J.W. 1965: The Biology of Hemichordata and Protochordata. VI + 176. Oliver and Boyd. Edinburgh and London.

Beklemishev, V.N. 1951: K postroeniju sistemy zhivotnych. Vtorichnorotyje Deuterostomia, ikh proizkhozhdenie i sostaw. Usp. Sovrem. Biol. 32, 256-270.

Beklemishev, W. N. 1970 (Russ. ed. 1952, 1964): Principles of Comparative Anatomy of Invertebrates. I/II, $490+529$. Oliver and Boyd Ltd. Edinburgh and Chicago Press.

Bohlin, B. 1950: The affinities of graptolites. Bull. geol. Inst. Univ. Uppsala, 34, 107-113.

Brommel, M. von, 1727: Lithographiae Suecanae. Acta lit. Sueciae Upsaliae, 1, 2. Uppsala.
Brongniart, A. 1828: Historie des vegetaux Fossiles. Paris.

Bulman, O. M. B. 1932: On the graptolites prepared by Holm, Pt 1. Ark. Zool. 24A, 8, 1-46, pls. 1-9.

Bulman, O. M. B. 1937: Carl Wiman's work on the structure of the Graptoloidea. Bull. geol. Instn. Uppsala, 27, 10-18.

Bulman, O. M. B. 1938: Graptolithina. In Schindewolf, O. H. (ed.). Handbuch der Paläozoologie. Z D, 2, 1-92. Berlin.

Bulman, O. M. B. 1942; The structure of the dendroid graptolites. Geol. Mag. 79, 284-290.

Bulman, O. M. B. 1945: A monograph of the Caradoc (Balclatchie) graptolites from limestones in Laggan Burn, Ayrchire. Palaeontogr. Soc. (Monographs), 1, 1-42.

Bulman, O. M. B. 1948: The Anatomy and Classification of the Graptolites. Rep. XIII Congres Int. Zoologie (Paris 1948), 529-535.

Bulman, O. M. B. 1955; Graptolithina with sections on Enteropneusta and Pterobranchia. In Moore, R. C. (ed.). Treatise on Invertebrate Paleontology, V (1st edition), Geol. Soc. and Univ. of Kansas Press, XVII + 101.

Bulman, O. M. B. 1970: Graptolithina with sections on Enteropneusta and Pterobranchia. In Teichert, C. (ed.). Treatise on Invertebrate Paleontology, V (2st edition), Geol. Soc. Am. and Univ. of Kansas Press, XXXI + 163.

Crowther, P. R. 1980: The fine structure of graptolite periderm, Special Papers in Palaeontology, 26, 1-119.

Crowther, P. R. and Rickards, R. B. 1977. Cortical bandages and the graptolite zooid. Geologica Palaeont., 11, 9-46.

Dawydoff, C. 1948: Embranchement des Stomochordés. In Grassé, P.-P. (ed.) Traité de Zoologie, 11, 367-489, Masson. Paris.

Decker, Ch. E. 1956: Place of graptolites in animal kingdom. Bull. Am. Assoc. Petr. Geol. 40, 1699-1704.

Decker, Ch. E. and Hassinger, N. 1958: What higher magnification is doing for the study of graptolithes. J. Paleont., $32,697-700$, pls. 95-97.

Dilly, P. N. 1971: Keratin-like fibres in the hemichordate Rhabdopleura compacta. Z. Zellforsch. mikrosk. Anat., 117, 502-515.

Elles, G. L. 1922: The graptolite faunas of the British Isles. A study in evolution. Proc. Geol. Assoc. 33, 168-200.

Foucart, M. F. 1964: Paléontobiochemie et position systématiques des graptolites. Univ. Liège. Mem. de Licence, 1120. Liège.

Foucart, M. F. Bricteux-Gregoire, S., Jeuniaux, C. and Florkin, M. 1965: Fossil proteins of graptolites. Life Sci. 4, 467-471.

Foucart, M. F. and Jeuniaux, C. 1966: Paléobiochemie et position systématique des graptolithes. Annls. Soc. zool. Belg. $95(2), 39-45$.

Frech, F. 1897: Graptolithiden. pp. 544-684. pls. A-B, In: Lethaea geognostica. 1. Theil. Lethaea palaeozoica, Stuttgart.

Hall, J. 1865. Graptolites of the Quebec Group. Geol. Surv. Can. Organic Rems, dec. 2, 1-151, pls. A-B, 1-21.

Hyman, L. H. 1959: The Invertebrates V. Smaller Coelomate Groups. V + 783. Mc Graw-Hill Book Comp. New YorkLondon - Toronto.

Kirk, N. H. 1972: Some thoughts on the construction of the rhabdosome in the Graptolithina, with special reference to extrathecal tissue and its bearing on the theory of automobility. Univ. Coll. Wales, Aberystwyth, Dept. Geol. Publ. 1, 1-21, pls. 1-5.

Kirk, N. H. 1974: More thoughts on the construction of the rhabdosome in the Dendroidea, in the light of the ultrastructure of the Dendroidea and Mastigograptus, Univ. Coll. Wales, Aberystwyth, Dept. Geol. Publ., 6, 1-11.

Kozlowski, R. 1938: Informations preliminaires sur les Graptolithes du Tremadoc de la Pologne et sur leur portée théorique. Ann. Mus. Zool. Polon. 13, 183-196.

Lapworth, C. 1873: Notes on the British graptolites and their 
allies. I. On an improved classification of the Rhapdophora. Geol. Mag., 10, 500-504, 555-560.

Linnaeus (Linné), C. 1735: Systema Naturae. 1st ed.... Lugduni Batavorum.

Nicholson, H. A. 1872: Monograph of the British Graptolitidae. $X+133$. Blackwood and Sons. Edinburgh and London.

Perner, J. 1894: Etudes sur les Graptolites de Boheme. $1^{\mathrm{i} e r}$ partie: Structure microscopique des genres Monograptus et Retiolites 14 pp., 3 pls. Prague.

Popper, K. 1979: Objective knowledge. An evolutionary approach. X +395 . Clarendon Press, Oxford.

Richter, R. 1871: Aus dem Thuringschen Schiefergebirge. Zeitschr. d. Deutsch. Geol. Gesell., 23, 231-256.

Ruedemann, R. 1894: Development and mode of growth of $\mathrm{Di}$ plograptus McCoy. Rep. St. Geol. N.Y. 14, 217-249, pls. $1-5$.

Schepotieff, A. 1905: Ueber die Stellung der Graptolithen im zoologischen System. N. Jahrb. f. Mineralogie 2, 79-98.

Simpson, G. G. 1953: The major features of evolution. 434 pp. Columbia Univ. Press, New York.

Towe, K. M. and Urbanek, A. 1972: Collagen-like structures in Ordovician Graptolite periderm. Nature, Lond. 237, 443445 .
Urbanek, A. 1976: The problem of graptolite affinities in the light of ultrastructural studies on peridermal derivatives in pterobranchs. Acta Palaeont. Polon., 21, 3-36, pls. 1-7.

Urbanek, A. 1986: The enigma of graptolite ancestry; Lesson from a phylogenetic debate. In Hoffman, A. and Nitecki, M. H. (eds.) Problematic fossil Taxa. Oxford Univ. Press. New York - Oxford, 184-226.

Urbanek, A. and Towe, K. M. 1974: Ultrastructural studies on graptolites, 1: The periderm and its derivatives in the Dendroidea and Mastigograptus. Smithson. Contr. Paleobiol. $20,1-48$, pls. $1-30$.

Urbanek, A. and Towe, K. M. 1975: Ultrastructural studies on graptolites in the Graptoloidea. Smithson. Contr. Paleobiol. 22, 1-48, pls. 1-24.

Walch, J. E. I. 1771: Naturgeschichte der Versteinerungen zur Erläuterung deer Knorr'schen Sammlung von Merkwürdigkeiten der Natur. Suppl. 3, Nürnberg.

Waterlot, G. 1953: Classe des Graptolites. In: Piveteau, J. (ed.). Traité Paléontologie, III, 968-997.

Wiman, C. 1895: Ueber die Graptolithen. Bull. Geol. Inst. Univ. Uppsala, 2, 239-316, pls. 9-15. 